\title{
Migration of human mesenchymal stem cells stimulated with pulsed electric field and the dynamics of the cell surface glycosylation
}

\author{
Katarzyna Jezierska-Woźniakk ${ }^{1, A-D}$, Seweryn Lipiński2, ${ }^{2, D}$, Margaret Huflejt, ${ }^{3, A, C, D}$, Łukasz Grabarczyk ${ }^{3, B}$, Monika Barczewska ${ }^{3, A, C}$, \\ Aleksandra Habich ${ }^{4, B}$, Joanna Wojtkiewicz ${ }^{5, C}$, Wojciech Maksymowicz ${ }^{3, A, F}$ \\ ${ }^{1}$ Department of Neurology and Neurosurgery, Faculty of Medical Sciences, Laboratory for Regenerative Medicine, University of Warmia and Mazury in Olsztyn, Poland \\ ${ }^{2}$ Department of Electric and Power Engineering, Electronics and Automatics, Faculty of Technical Sciences, University of Warmia and Mazury in Olsztyn, Poland \\ ${ }^{3}$ Center of Innovative Research in Medical and Natural Sciences, Faculty of Medicine, University of Rzeszów, Poland \\ ${ }^{4}$ Department of Pathophysiology, Faculty of Medical Sciences, University of Warmia and Mazury in Olsztyn, Poland \\ A - research concept and design; $\mathrm{B}$ - collection and/or assembly of data; $\mathrm{C}$ - data analysis and interpretation; \\ $D$ - writing the article; $E$ - critical revision of the article; $F$ - final approval of the article
}

Address for correspondence

Katarzyna Jezierska-Woźniak

E-mail: Katarzyna.jezierska@uwm.edu.pl

\section{Funding sources}

The study was funded from the National Science Center (NCN); grant No. 2012/07/B/NZ4/01427.

Conflict of interest

None declared

Received on September 19, 2017

Reviewed on January 2, 2018

Accepted on May 8, 2018

\begin{abstract}
Background. The analysis of the stem cells' glycome dynamics at different stages of differentiation and migration makes possible the exploration of the cell surface glycans as markers of the stem cell functional status, and, in the future, compatibility between transplanted cell and host environment.

Objectives. The objective of our study was to develop novel techniques of investigating cell motility and to assess whether the electric field of the therapeutic spinal cord stimulation system used in vivo contributes to the migration of human mesenchymal stem cells (hMSCs) in vitro.

Material and methods. We have investigated the electrotaxis of bone marrow-derived MSCs using pulsed electric field (PEF) in the range of $16-80 \mathrm{mV} / \mathrm{mm}$ and the frequency of $130 \mathrm{~Hz}$ and $240 \mathrm{~Hz}$. The PEF-related dynamics of the cell surface glycosylation was evaluated using 6 plant lectins recognizing individual glycans.

Results. Pulsed electric field at physiological levels $(10 \mathrm{mV} / \mathrm{mm} ; 130 \mathrm{~Hz})$ did not influence cellular motility in vitro, which may correspond to the maintenance of the transplanted cells at the lesion site in vivo. An increase of the PEF intensity and the frequency exceeding physiological levels resulted in an increase in the cellular migration rate in vitro. Pulsed electric field elevated above physiological intensity and frequency $(40-80 \mathrm{mV} / \mathrm{mm} ; 240 \mathrm{~Hz})$, but not at physiological levels, resulted in changes of the cell surface glycosylation.

Conclusions. We found the described approach convenient for investigations and for the in vitro modeling of the cellular systems intended for the regenerative cell transplantations in vivo. Probing cell surface glycomes may provide valuable biomarkers to assess the competence of transplanted cells.
\end{abstract}

Key words: translational medicine, mesenchymal stem cells migration, stem cells homing, pulsed electric field, stem cell glycosylation

D0I

10.17219/acem/90872

Copyright

Copyright by Author(s)

This is an article distributed under the terms of the

Creative Commons Attribution Non-Commercial License

(http://creativecommons.org/licenses/by-nc-nd/4.0/) 


\section{Introduction}

Stem cell therapy encompasses new technologies and therapies aiming at replacing damaged cells with healthy ones. However, there are still several challenges that must be tackled before such therapies become successful. One of these challenges is the migration of transplanted cells, fundamental both to the development and maintenance of regenerated tissues as well as to the success of the cellbased therapies. Therefore, precise localization of these cells directly into the injury site and their adaptation to host tissues are crucial for the success of therapy.

Delivering transplanted cells precisely at the lesion site is still an unsolved problem of cell therapy. This process, termed homing, is a major road-block in stem cell therapy due to the poor integration of transplanted stem cells with targeted host tissue. This results in poor healing responses and lack of regeneration. The main reason for poor cell homing is likely due to the fact that only a small fraction of injected cells migrate to the damaged tissue and are able to act therapeutically. ${ }^{1}$ It is also critical to demonstrate that MSCs do not have unwanted homing that could drive undesirable differentiation and growth. ${ }^{2}$

The cells migrate in response to gradients in chemical composition (chemotaxis), mechanical forces and electric fields (galvanotaxis or electrotaxis). Natural electric fields (EFs) are present in all developing and regenerating tissues. Furthermore, damaged tissues and wounds also generate naturally-occurring endogenous EFs essential in guiding cell migration. ${ }^{3}$ Endogenous EFs have been identified and measured in various species, tissues and organs in vitro and in vivo. ${ }^{4,5}$ It has been shown that many cell types respond to applied EFs in vitro at the field strengths comparable to the endogenous wound EFs in vivo. The bioelectricity plays an important role in moving cells in a specific direction. Rat osteoblasts, bovine chondrocytes and mouse endothelial progenitor cells migrate towards the cathode, while rabbit osteoclasts, human osteosarcoma cells, rabbit corneal endothelial cells, or human umbilical vein endothelial cells migrate in the opposite direction. ${ }^{6-8}$ These different responses indicate that the effects of electric current are cell type- and species-dependent. Consequently, an applied electric field may be used as a cue to guide directional migration of stem cells in the cell-based therapies. ${ }^{9}$

The most common assays for the in vitro electrotaxis studies employ a cell culture dish attached to an electrotaxis apparatus. ${ }^{5,10}$ Microfluidic devices allowing better control of the electric field and cell migration environments have been recently developed. ${ }^{11}$ New solutions, providing advanced experimental tools for electrotaxis research, improving productivity and enabling studies of the more complex cell migration environments, have also been recently reported. ${ }^{12-14}$ However, these experimental tools allow investigations of cellular motility only in laboratory conditions, making transfer of the favorable experimental findings to the clinical setting difficult.
One of the major macromolecular systems defining cellcell and cell extracellular matrix interactions is the cell glycome consisting of a large variety of complex glycans covalently attached to the membrane proteins and lipids. ${ }^{15}$ These glycoproteins and glycolipids are actively involved in, and often control, cell-cell signaling, immune response, would healing, microbial infections, and other events on the cellular and tissue levels. The dynamics of glycomic profile reflects changes in the cellular activities such as division, differentiation, motility, secretory functions, and malignant transformation. Cell glycosylation-targeting investigations would, therefore, be expected to streamline the discovery of novel biological factors of potential clinical significance in regenerative medicine.

The aim of this study was to develop a novel technique for cell motility investigations and to assess whether the system used for spinal cord stimulation is able to direct the migration of MSCs in vitro. We first used pulsed electric field (PEF) to observe the phenomena of MSCs electrotaxis. Using time-lapse video microscopy, we demonstrated and analyzed the direct migration of the MSCs in the PEF. Additionally, using 6 plant lectins, we also evaluated changes in the cell surface glycosylation resulting from the stimulation of cells with PEF.

\section{Methods}

\section{Cell culture}

We used adult human MSCs derived from the bone marrow remaining after the hip replacement. The experimental design has been approved by the Ethic Committee of University of Warmia and Mazury in Olsztyn, Poland. Written informed consent was obtained from each participant prior to the study enrollment. Mesenchymal stem cells were isolated from the bone marrow according to their adhesive properties to tissue culture plastic under sterile conditions. Briefly, a phosphate-buffered saline (PBS)-diluted cell fraction of bone marrow was layered over a Ficoll density gradient (1.077 g/mL; GE Healthcare, Chicago, USA), followed by centrifugation at $400 \mathrm{~g}$ at room temperature for $40 \mathrm{~min}$. Nucleated cells were collected, diluted with 2 volumes of PBS (Sigma-Aldrich, St. Louis, USA), centrifuged twice at $100 \mathrm{~g}$ for $10 \mathrm{~min}$, and finally resuspended in a culture medium. Cells were plated at a density of 1,500 cells $/ \mathrm{cm}^{2}$ in a T75 flask and serially passaged at sub-confluence every 5-7 days at the same initial density. Cells were maintained in the Dulbecco's Modified Eagle Medium (DMEM) growth medium supplemented with $10 \%(\mathrm{v} / \mathrm{v})$ FBS (Sigma-Aldrich) and 1\% (v/v) antibiotics 1\% 10,000-U penicillin/streptomycin (P/S) (Sigma-Aldrich), at $37^{\circ} \mathrm{C}$ in an air- $5 \% \mathrm{CO}_{2}$ incubator. For the evaluation of the EF-dependent changes in the cell surface, glycan profiles cells were seeded on the thin glass slides and treated with the EF stimulation using parameters described below. 


\section{Electric field stimulation and time lapse image recording}

Cells $\left(1,500\right.$ cells $\left./ \mathrm{cm}^{2}\right)$ were seeded and grown for at least $12 \mathrm{~h}$ in culture conditions as described above. To test the effect of EF and to ensure a constant flow of current, in case of an impendence drop, temperature change and other similar technical issues, a PEF was applied through bipolar electrode (St. Jude Medical Inc., Saint Paul, USA). Electric field intensities of $4 \mathrm{~mA}(16 \mathrm{mV} / \mathrm{mm}), 10 \mathrm{~mA}(40$ $\mathrm{mV} / \mathrm{mm})$ and $20 \mathrm{~mA}(80 \mathrm{mV} / \mathrm{mm})$ were used in the experiments, with exposure times of 3, 6 and $9 \mathrm{~h}$. Stimulation frequencies were set at $130 \mathrm{~Hz}$ and $240 \mathrm{~Hz}$, respectively to the field intensities. The pulse wave was set to $200 \mathrm{~ms}$.

Time-lapse imaging was performed using an inverted microscope (JuLi FL; NanoEntek; Seoul, South Korea) to digitally record MSC migration. Images were acquired every $15 \mathrm{~min}$. For long-term observations, the cell cultures as well as the PEF stimulation device were kept in the air$\mathrm{CO}_{2}$ incubator. At the end of the exposure period, cells were fixed in the PBS-buffered $4 \%$ formalin and then digitally photographed for quantification.

\section{Evaluation of cells movement}

Each migrating cell was traced using the position of the centroid of the plane figure, covering the area occupied by the cell in image obtained for each timeframe. A human operator generated an outline of each cell manually.
The centroid of the cell represents the cell's center of gravity, with coordinates as given in ${ }^{16}$ :

$$
\begin{aligned}
& X=\frac{1}{\sum_{i=1}^{M} \sum_{j=1}^{N} I\left(x_{i}, y_{j}\right)} \sum_{i=1}^{M} \sum_{y=1}^{N} x_{i} \cdot I\left(x_{i}, y_{j}\right) \\
& Y=\frac{1}{\sum_{i=1}^{M} \sum_{j=1}^{N} I\left(x_{i} y_{j}\right)} \sum_{i=1}^{M} \sum_{y=1}^{N} y_{j} \cdot I\left(x_{i}, y_{j}\right)
\end{aligned}
$$

where:

$\mathrm{M}, \mathrm{N}$ - image dimensions,

$I\left(x_{i}, y_{i}\right)$ - value of the pixel with xi, yi coordinates (in our case each image contains binary information and so $I\left(x_{i}, y_{i}\right)$ equals 1 when pixel of these coordinates represents area covered by the cell, otherwise it is equal to 0 .

Using the center of gravity to localize the so-called "blob" (i.e., a figure of an irregular shape) in a binary image is a commonly used approach and can be successfully utilized in experimental applications. ${ }^{18,19}$ Figure 1 shows the centroid obtained for a sample cell. Based on the locations of the cells in each time frame, the parameter of distance was calculated section-by-section and as the straight-line distance between the $1^{\text {st }}$ and the last frame, to obtain information about the linearity of migration, which can be evaluated through the straightness factor, i.e., the ratio of the straight-line distance to the total distance. All measurements were made in triplicates.

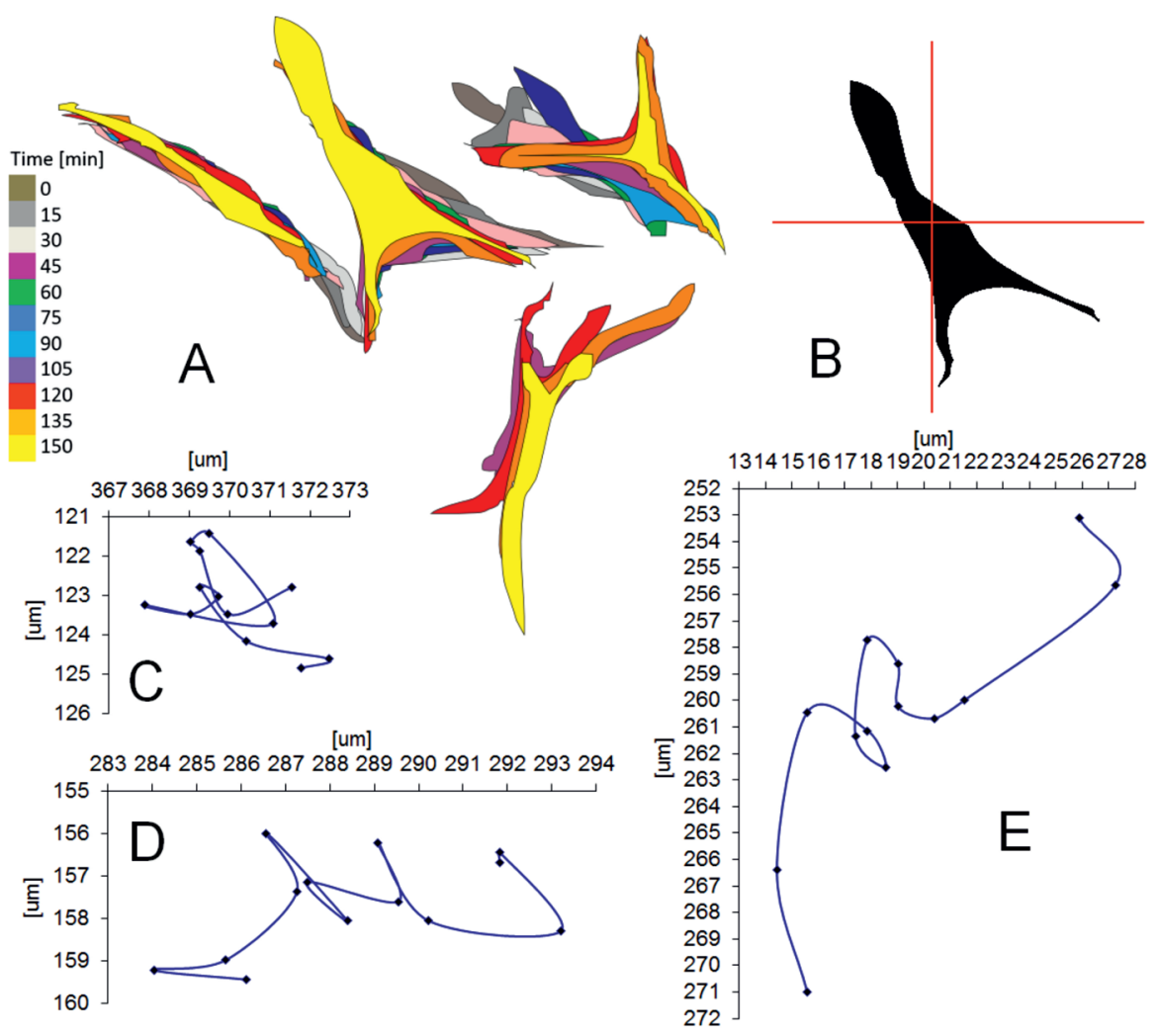

Fig. 1. A - manually outlined contours of 4 exemplary cells obtained by the time-lapse imaging; each color defines different time point; $B$ - centroid of the exemplary cell indicated by the intersection of the red lines; C, D, E- migration pathways of 3 exemplary cells under different experimental conditions: $\mathrm{C}-4 \mathrm{~mA}, 130 \mathrm{~Hz}$; D $10 \mathrm{~mA}, 130 \mathrm{~Hz}$; $\mathrm{E}-20 \mathrm{~mA}, 130 \mathrm{~Hz}$. 


\section{Cell viability}

Cell survival was assessed using a commercial assay The CellTiter 96 AQueous One Solution Cell Proliferation Assay (Promega, Madison, USA), according to the manufacturer's protocol.

\section{Lectin binding}

Following PEF treatment, cells were washed twice with PBS and fixed immediately for $15 \mathrm{~min}$ in the PBS-buffered $4 \%$ formalin. The carbohydrate phenotype was analyzed using 6 biotinylated lectins of plant origin: Aleuria aurantia (AAL), Hippeastrum hybrid, a maryllis (HHL), Sambucus nigra (SNA), Narcissus pseudonarcissus (NPL), wheat germ agglutinin (WGA), and concanavalin A (CON A)

Table 1. Lectins used in this study and their glycan-binding specificity

\begin{tabular}{|c|c|}
\hline Lectin & Binding specificity \\
\hline AAL (Aleuria aurantia) & a1,6 L-fucose \\
\hline $\begin{array}{l}\text { HHL (Hippeastrum hybrid } \\
\text { - amaryllis) }\end{array}$ & a 1,3 and a1,6 mannose \\
\hline SNA (Sambucus nigra) & Neu5Ac a2,6Gal or a2,6GalNAc \\
\hline $\begin{array}{l}\text { NPL (Narcissus } \\
\text { pseudonarcissus) }\end{array}$ & a Man, (a1,6) galactomannans \\
\hline $\begin{array}{l}\text { WGA (wheat germ } \\
\text { agglutinin) }\end{array}$ & 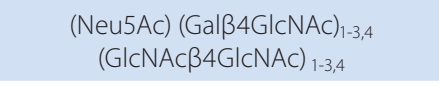 \\
\hline CON A (concanavalin A) & Terminal a Man, Man a3[Man a6] Man \\
\hline
\end{tabular}

(Table 1). All lectins were purchased from Vector Labs (San Diego, USA). Fixed cells were incubated with $2 \mu \mathrm{g} /$ $\mathrm{mL}$ of each biotinylated lectin overnight, washed 3 times with PBS and incubated with FITC-streptavidin (Invitrogen) and Cy3-streptavidin (Invitrogen, Carlsbad, USA), in 1:2,000 dilution. Cellular nuclei were stained with the Hoechst 33258 dye (Sigma-Aldrich).

\section{Results}

\section{Evaluation of cellular movement}

The experiment was conducted in 2 steps. The $1^{\text {st }}$ step aimed to determine whether the frequency of the pulsed electric field had an impact on the cell movement. As our preliminary results indicate, cellular motility increases with the value of the EF; therefore, we used 2 frequencies, 130 and $240 \mathrm{~Hz}$, of the highest value of field intensity, i.e., $80 \mathrm{mV} / \mathrm{mm}$, with $3 \mathrm{~h}$ observation time. We evaluated statistical differences in the total distance (i.e., distance measured section by section), as well as in the straight-line distance. The one-way analysis of variance (ANOVA) test, with a significance level (p-value) equal to 0.05 , showed that there was no significant difference between any pair of data (pair of values). In conclusion, there was no reason to continue the experiment using various frequencies, so we chose $130 \mathrm{~Hz}$ for further evaluation of cellular movement.

In the $2^{\text {nd }}$ step, we used PEFs with intensities equal to 4,10 and $20 \mathrm{~mA}$, and collected data for control group $(0 \mathrm{mV} / \mathrm{mm})$. For the data statistical analysis, we used Kruskal-Wallis $\mathrm{H}$ test (with 0.01 significance level), followed by multiple comparison test using post-hoc Fisher's least significant difference (LSD) test (with 0.05 significance level) in order to obtain pairwise comparison results. Matlab R2 013b Statistics (MathWorks, Natic, USA) and Machine Learning Toolbox were used for the purpose of all the abovedescribed statistical analysis. The results were as follows:
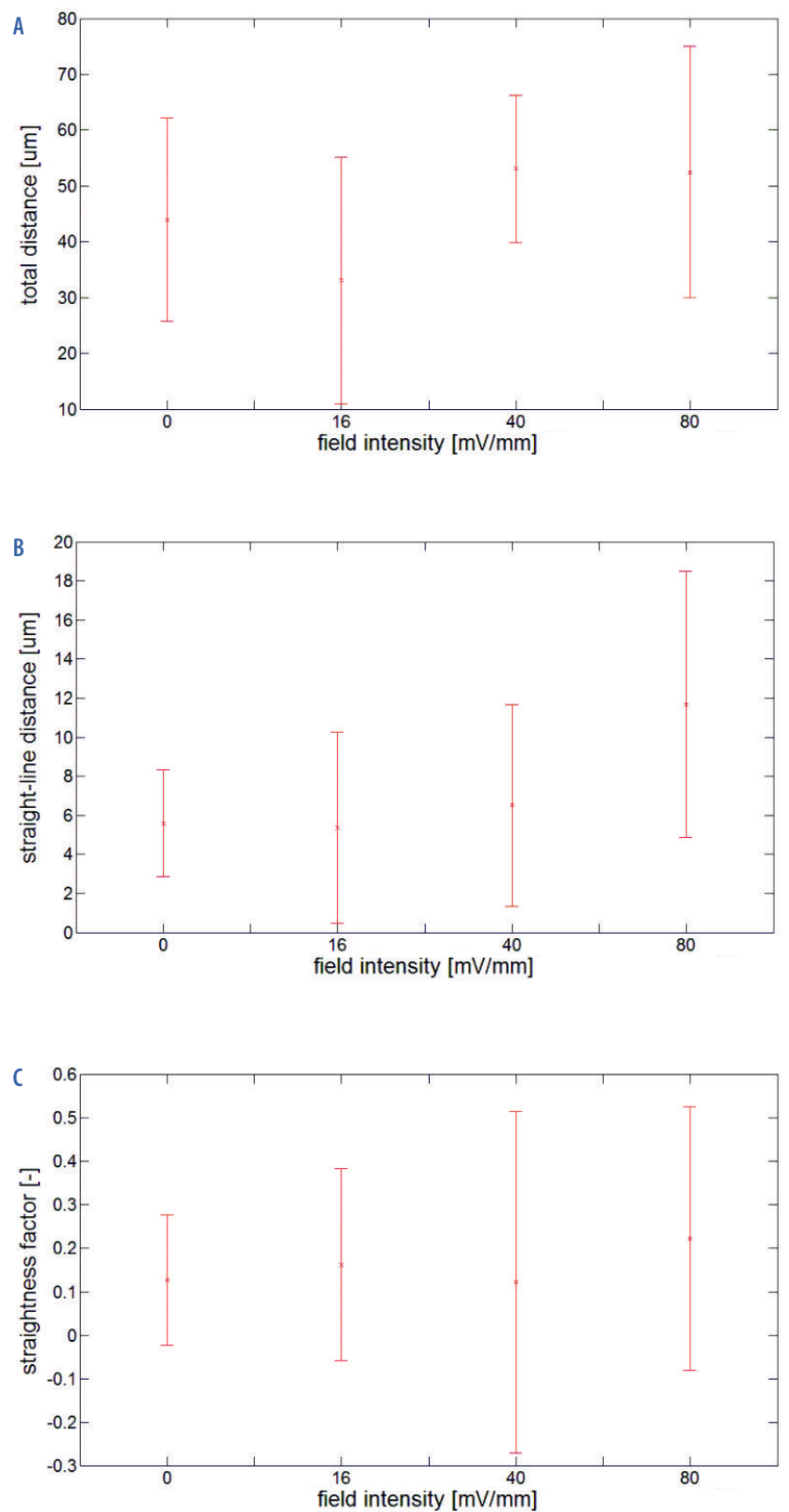

Fig. 2. Distance $[\mu \mathrm{m}]$ covered by 15 randomly selected mesenchymal stem cells (MSCs) during migration in pulsed electric field (0-20 mA; $130 \mathrm{~Hz}$ ), measured in the time-lapse image

A - total distance; B - straight line distance; C - straightness factor. 
- there were statistical differences between data on straight-line distance (Fig. 2A); between data on straight-line distance obtained for filed values equal to 4 and $10 \mathrm{mV} / \mathrm{mm}$ and data obtained for filed value equal to $20 \mathrm{mV} / \mathrm{mm}$;

- there were statistical differences between data for straightness factor obtained for field values equal to 4 and $10 \mathrm{mV} / \mathrm{mm}$ and data obtained for field value equal to $20 \mathrm{mV} / \mathrm{mm}$ (Fig. $2 \mathrm{~B}$ )

- there were no statistical differences between data on total distance (Fig. 2C); in other words, the test confirmed the null hypothesis that all 4 data samples (control group and 3 values of PEF intensity) come from the same distribution; in addition, there were no statistical differences between data on straight-line distance between control $(0 \mathrm{mV} / \mathrm{mm})$ and experimental data for field values equal to 4 and $10 \mathrm{mV} / \mathrm{mm}$.

Presented figures depict cell images representative for given conditions.

\section{Influence of pulsed electric field stimulation on the cell glyco-phenotype}

We performed a comparative analysis of surface glycosylation in MSC population after PEF stimulation, using a panel of plant lectins shown in Table 1, known to bind certain structural oligosaccharides present in human cells. Staining with the fluorescein-labeled lectins has revealed the dynamics of terminal and internally linked $\alpha 1,3$ and $\alpha 1,6 \mathrm{fu}-$ cose, $\alpha 1,3$ and $\alpha 1,6$ mannose, $\alpha 2,6$ sialic acid, and terminal $\mathrm{N}$-acetylglucosamine (GlcNAc), both on the cell surface and in intracellular localizations.

Cells from the control group untreated with the EF were positive for all analyzed lectins. Staining with Hippeastrum hybrid (HHL), Sambucus nigra (SNA), wheat germ agglutinin (WGA) and Aleuria aurantia (AAL) showed glycans located within endoplasmic reticulum and Golgi apparatus (ER/G). Concanavalin A (Con A) and Narcissus pseudonarcissuss (NPL) gave signals from both Golgi apparatus and from cytoplasm. We observed signals within different compartments of ER, both in the Golgi vesicles and around the nucleus. Signals closed to the nucleus varied depending on the direction of the EF. In certain EF conditions, signals appeared highly concentrated, forming a very characteristic cap on one side of the nucleus, called here "polarized ER" (ERp). Moreover, AAL, Con A, SNA and WGA were all highlighting multiple cell-cell contact points. Staining for Con A and WGA revealed specific points of cell attachment to the bottom of the culture dishes (glass, bottom substratum). Only in the case of these 2 lectins, the entire cell membrane was outlined by lectin signals in control cells, but following the EF stimulation, staining was reduced to only specific membrane foci, suggesting membrane rearrangements or fusion of newlymade membrane domains.

To compare the dynamic of complex glycans containing different types of mannose (Man) linkages, 3 mannose-binding lectins were used. High amounts of $\alpha$-mannopyranosyl groups are present, as indicated by strong staining with Con A recognizing the internal branched Man core trisaccharide (Man $\alpha 1,6[\operatorname{Man} \alpha 1,3]$ Man) of N-linked glycans. HHL binds glycans with both $(\alpha 1,3)$ - and $(\alpha 1,6)$-linked mannose structures, while NPL has a specificity towards $\alpha$-linked mannose preferring polymannose structures containing $(\alpha 1,6)$ linkages. The presence of poly-N-acetyllactosaminyl chains (LacNAc) was clearly demonstrated by the intense WGA staining and the presence of sialic acid in a $(\alpha 2,6)$ linkage $(\mathrm{Neu} 5 \mathrm{Ac} \alpha 2,6)$ was shown by the SNA specific for Neu5Ac 2 2,6Gal/GalNAc. The orange peel fungal lectin (Aleuria aurantia lectin AAL) indicated $\alpha 1,6$-linked fucosyl groups occuring on the N,N'-diacetylchitobiosyl residues in N-linked glycoproteins.

The EF stimulation resulted in the re-distribution of glycans shown by all 6 lectins (Fig. 3) in both individual signal intensities and localizations. Table 2 presents key observations made during analyses of lectin staining patterns of glycan expression and localization.

Signals produced by AAL and SNA bindings behaved very similarly. Under exposure to high frequency $(240 \mathrm{~Hz}) \mathrm{EF}$, target-glycans binding by AAL disappeared, there was no effect of current change on the AAL staining pattern, whereas an increase in the EF intensity resulted in the loss of SNA signal.

In the case of $\mathrm{CON} A$, a very characteristic staining pattern corresponding to membrane shedding, as well as deposits of cell debris and cellular secretions of CON Areactive materials were observed. In a few colonies, there were no CON-A-detectable cell-attachment sites away from the main cell population, but the cell-cell contact points were highlighted. This result could be explained by the different types of mannose linkages present in glycans in these locations.

Remodeling of cells surface glycosylation is also visualized by the HHL lectin. Initially visible clear ERp signal disappeared during the long exposure to the low field value and frequency, completely changing cellular localization by moving to the Golgi apparatus. The high frequency EF resulted in the loss of the HHL signal. We can hypothesize that the polarization of HHL-highlighted ER (ERp) demonstrated a polarization of the cell membrane components following cell motion direction.

\section{Cell viability}

To verify that MSCs were not damaged by applied PEFs, the viability of cells following a $3 \mathrm{~h}, 6 \mathrm{~h}$ and $9 \mathrm{~h}$ culture exposed to the PEF was compared with that of cells cultured for the same time under similar conditions but without PEF. The viability of cells following a $3 \mathrm{~h}, 6 \mathrm{~h}$ and $9 \mathrm{~h}$ culture of stimulation did not differ between groups ( $p>0.05$, one-way ANOVA). This suggests that the application of either low EF $(130 \mathrm{~Hz}, 4 \mathrm{~mA})$ or high EF $(240 \mathrm{~Hz}, 20$ $\mathrm{mA}$ ) within a certain period of time did not result in any measurable damage to the cells. 
Table 2. Description of the surface glycans profile changes caused by stimulation of pulsed electric field (PEF)

\begin{tabular}{|c|c|c|c|c|c|c|}
\hline \multirow{2}{*}{$\begin{array}{c}\text { Field value: } \\
\text { frequency/intensity/ } \\
\text { time [h] }\end{array}$} & \multicolumn{6}{|c|}{ Lectin } \\
\hline & $\mathrm{AAL}$ & CON A & $\mathrm{HHL}$ & NPL & SNA & WGA \\
\hline $\begin{array}{l}\text { Control/3 } \\
\text { Control/6 } \\
\text { Control/9 }\end{array}$ & $\begin{array}{c}\mathrm{ER} / \mathrm{G} \text {, cell } \\
\text {-substrate contacts } \\
+++\end{array}$ & $\begin{array}{l}\text { ER/G, ERp, cell membrane, } \\
\text { cell -substrate contacts }\end{array}$ & ERp & $\begin{array}{l}\text { ER/G, ERp } \\
\text { - mixed } \\
\text { population }\end{array}$ & $\begin{array}{l}E R / G, E R p-\text { mixed } \\
\text { population }\end{array}$ & $\begin{array}{c}\text { ER/G, ERp, cell } \\
\text { membrane } \\
\text { domains, cell-cell } \\
\text { contacts }\end{array}$ \\
\hline $130 / 4 / 3$ & $\begin{array}{c}\text { ER/G, cell-substrate } \\
+++ \text {, cell-cell } \\
\text { contacts }\end{array}$ & no change & no change & no change & no change & no change \\
\hline $130 / 4 / 6$ & $\begin{array}{c}\mathrm{ER} / \mathrm{G}, \text { cell substrate } \\
+\end{array}$ & $\begin{array}{c}\text { ER/G, ERp in single cells, cell- } \\
\text { substrate }\end{array}$ & $E R / G$ & no change & no change & no change \\
\hline $130 / 4 / 9$ & $\begin{array}{l}\text { ER/G, ERp, cell } \\
\text { substrate }+\end{array}$ & $\begin{array}{l}\text { ER/G, ERp, cell membrane } \\
\text { domains, cell-substrate }\end{array}$ & $E R / G$ & no change & $\begin{array}{c}\text { ER/G and ERp } \\
\text { - mixed population, } \\
\text { lost expression } \\
\text { in single cells }\end{array}$ & no change \\
\hline $130 / 20 / 3$ & $\begin{array}{l}\text { ER/G, ERp less, cell- } \\
\text { cell contact points } \\
\text { in single cells }\end{array}$ & $\begin{array}{l}\text { ER/G, ERp, cells with no } \\
\text { expression, cell membrane } \\
\text { domains, cell-substrate } \\
\text { in individual cells }\end{array}$ & no change & $\begin{array}{l}\text { decreased } \\
\text { of expression } \\
\text { in ER/G }\end{array}$ & no signal & $\begin{array}{l}\text { ER/G, cell } \\
\text { membrane } \\
\text { domains }\end{array}$ \\
\hline $\begin{array}{l}130 / 20 / 6 \\
130 / 20 / 9\end{array}$ & no change & no change & no change & no change & no signal & no change \\
\hline $\begin{array}{l}240 / 4 / 3 \\
240 / 4 / 6 \\
240 / 4 / 9 \\
240 / 20 / 3 \\
240 / 20 / 6 \\
240 / 20 / 9\end{array}$ & no signal & $\begin{array}{l}\text { ER/G, ERp, heterogenous } \\
\text { expression patterns, } \\
\text { membrane sheading and } \\
\text { deposits containing glyco- } \\
\text { molecules reach in Con A- } \\
\text { reactive mannose }\end{array}$ & no change & no change & no signal & no change \\
\hline
\end{tabular}

+++ - robust signal in all locations; ER - endoplasmic reticulum; G - Golgi apparatus; ERp - polarized endoplasmic reticulum; AAL - Aleuria aurantia; CON A - concanavalin A; HHL - Hippeastrum hybrid (amaryllis); NPL - Narcissus pseudonarcissus; SNA - Sambucus nigra; WGA - wheat germ agglutinin; ER/G - endoplasmic reticulum/Golgi apparatus.

\section{Discussion}

Aiming at a better understanding of human bone marrow-derived MSCs migration and at the development of new techniques to follow the stem cells motility, we analyzed the migration of MSCs in the absence of directional stimuli and in the presence of a PEF ranging from a low physiological level to the higher than physiological levels, using spinal cord stimulation system. For the first time we have also identified changes in the cell surface glycosylation resulting from it being stimulated with the PEF.

Most of the data on the in vitro electrotaxis has been obtained by exposing the cells to a direct electrical current. In these experiments, metal electrodes directly inserted into the medium, agar or in-house made salt bridges were used. ${ }^{10,20-23}$ Effects of alternating electrical current stimulation combined with the direct EF current of very low frequencies have been reported for migration of keratinocytes. ${ }^{24}$

Despite the successful use of these experimental tools, it is challenging to effectively address more advanced scientific questions and meet higher technical requirements for the rapidly growing electrotaxis research, as well as to measure the applicability of these protocols in clinical trials. To our knowledge, this is the first work showing the effect of a PEF on the directed migration of MSCs after the application of a dedicated system already used in clinical practice.

We performed the stimulation of the MSCs using low and high current and low and high frequencies. In our previous studies, we have shown that cellular motility increases with the increase of the EF. ${ }^{19}$ In this study we have also analyzed the effect of the frequency of the EF on cell motility. We used 2 frequencies, $130 \mathrm{~Hz}$ and $240 \mathrm{~Hz}$, with the highest value of field intensity, i.e., $80 \mathrm{mV} / \mathrm{mm}$, with $3 \mathrm{~h}$ observation time to assess the degree of migration. We evaluated statistical differences in the total distance (i.e., distance measured section by section), as well as in the straight-line distance. The one-way ANOVA test, with the significance level (p-value) equal to 0.01 , showed that there was no significant difference between any pair of analysed data. This is in agreement with the results obtained by Jahanshahi et al. for electrical stimulation of the progenitor cells in the motor cortex. Furthermore, the frequency range does not seem to play any major role in the effectiveness of the electrical stimulation on proliferation. ${ }^{25}$

We then analyzed 3 parameters of cell migration, such as total distance, distance in straight line and factor 


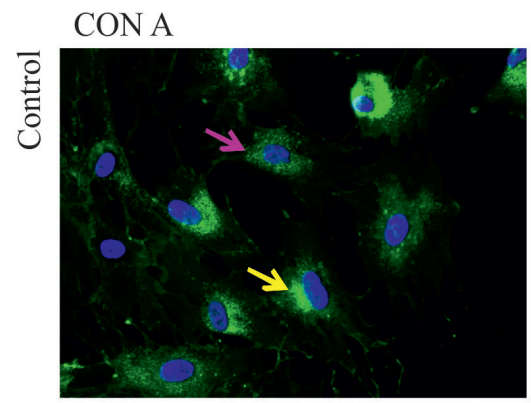

$\mathrm{HHL}$
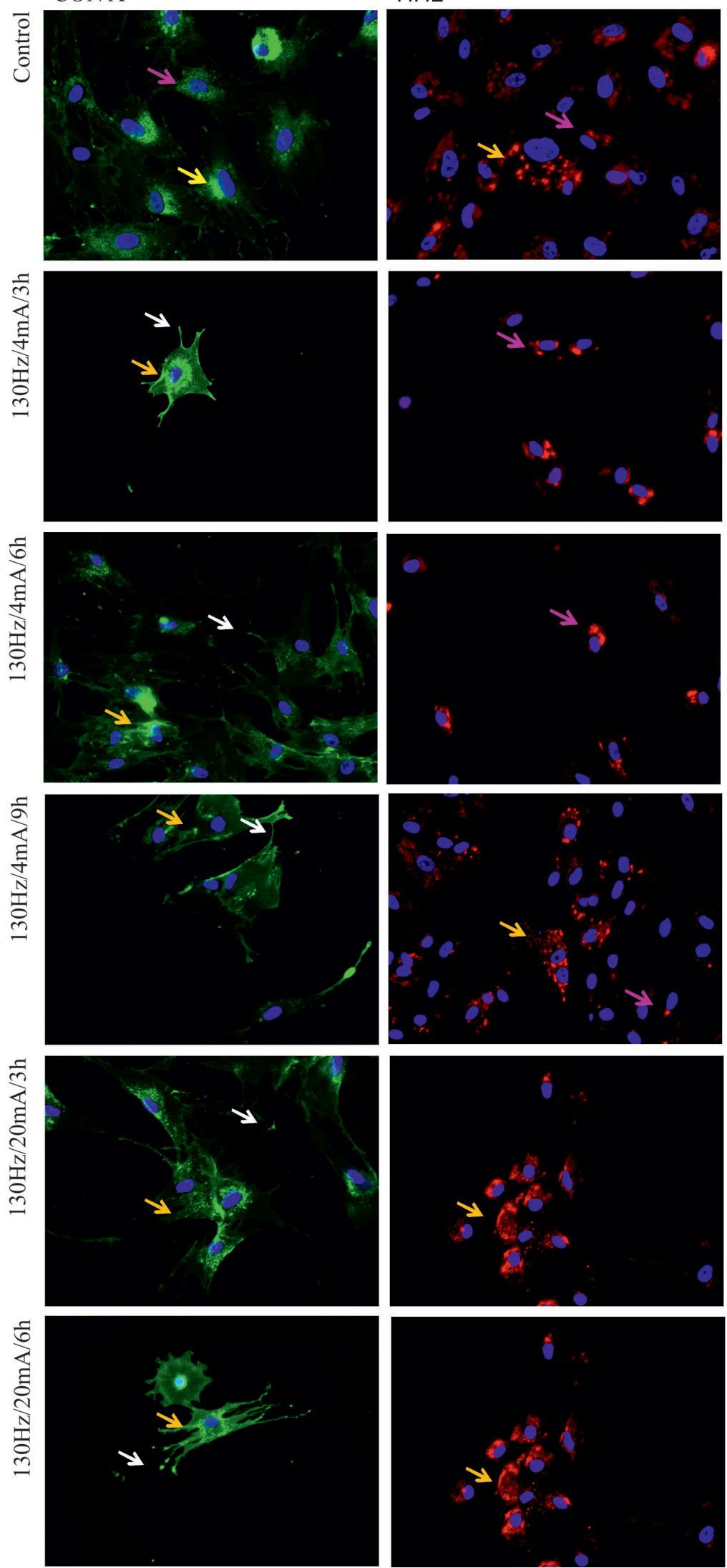

Fig. 3. Staining of selected glycans using fluorescence-labeled plant lectins in mesenchymal stem cells (MSCs) following stimulation in pulsed electric field (PEF), in conditions indicated on a left site of each row. Fluorescence labels: fluorescein-labeled streptavidin (green); Cy3-streptavidin (red); Hoechst nuclear stain (blue); $2 \mu \mathrm{g} / \mathrm{mL}$. Scale bar: $10 \mu \mathrm{m}$.

Arrows indicate: ER - endoplasmic reticulum (bright yellow); G - Golgi apparatus (orange); ERp - endoplasmic reticulum polarized (pink); cell-cell and cellsubstrate contact points (white).

NPL
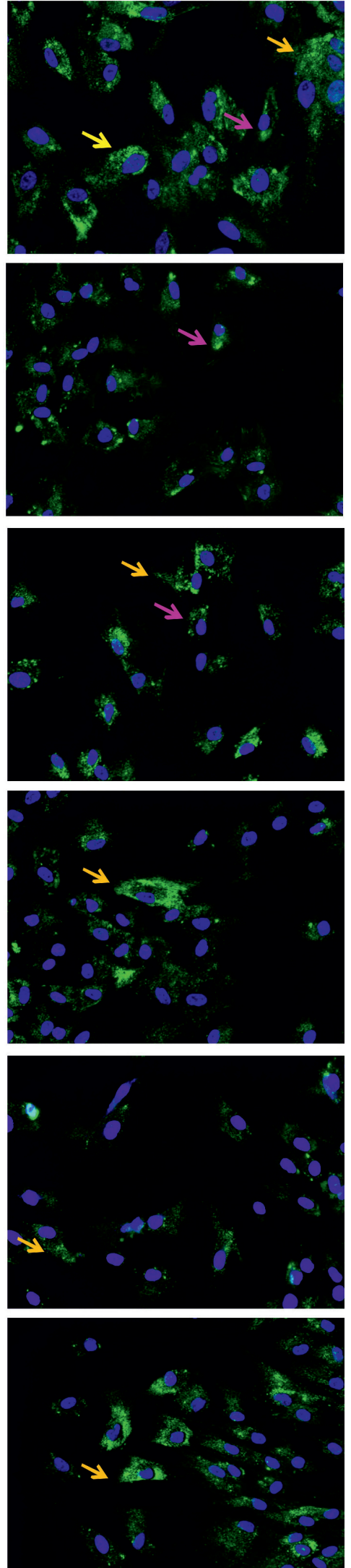


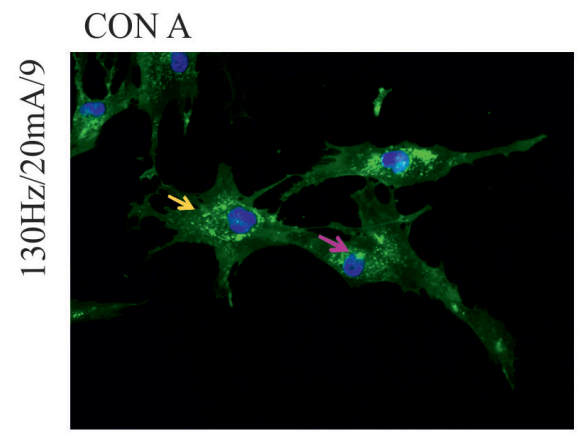

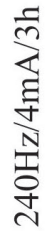
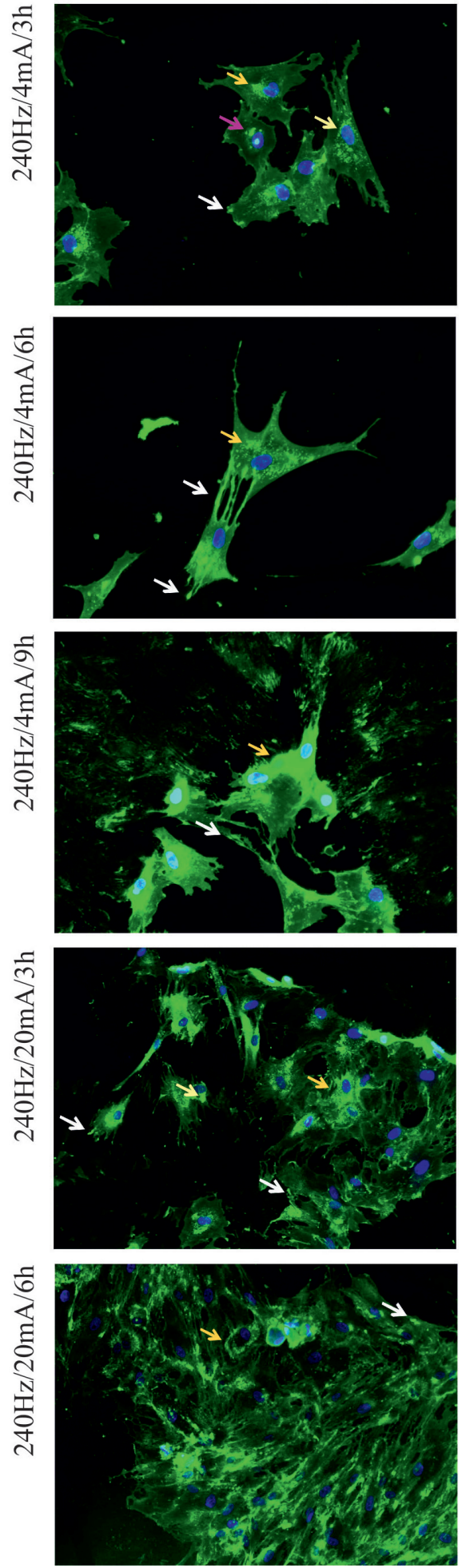

Fig. 3. Cont.

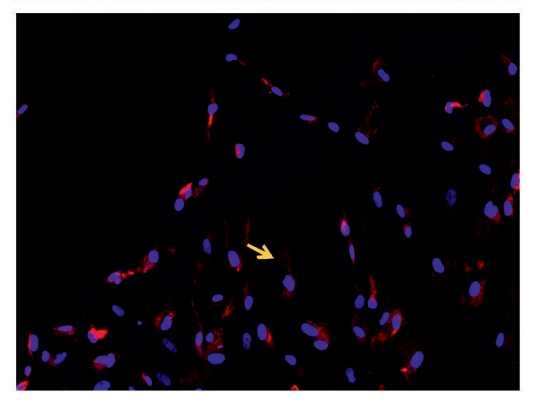

$\mathrm{HHL}$

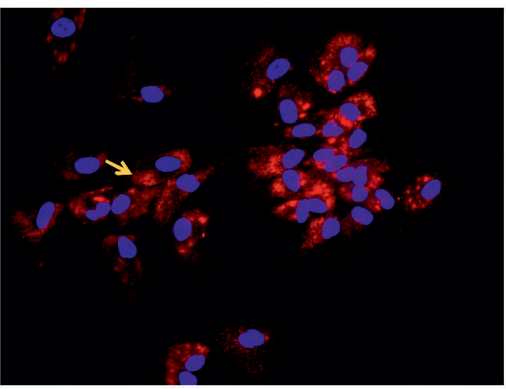

NPL
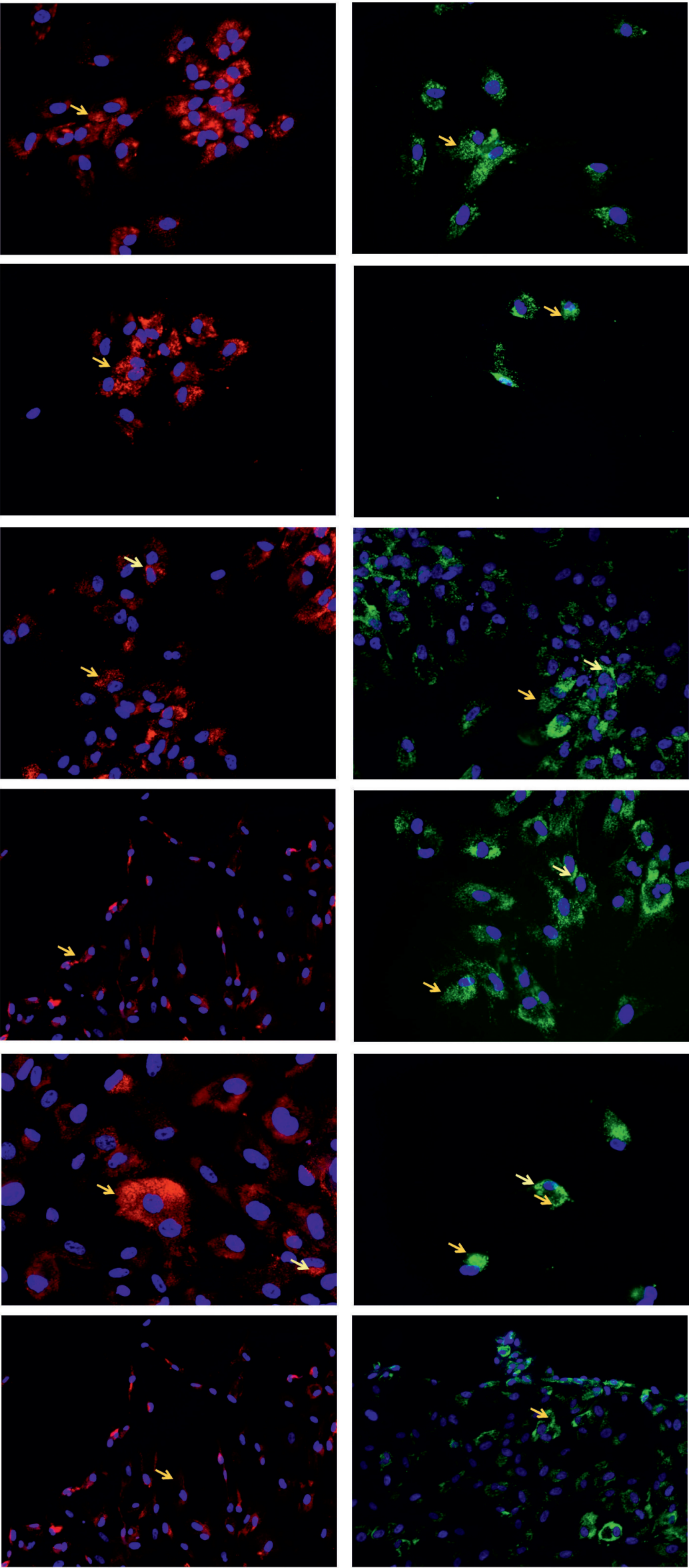

3



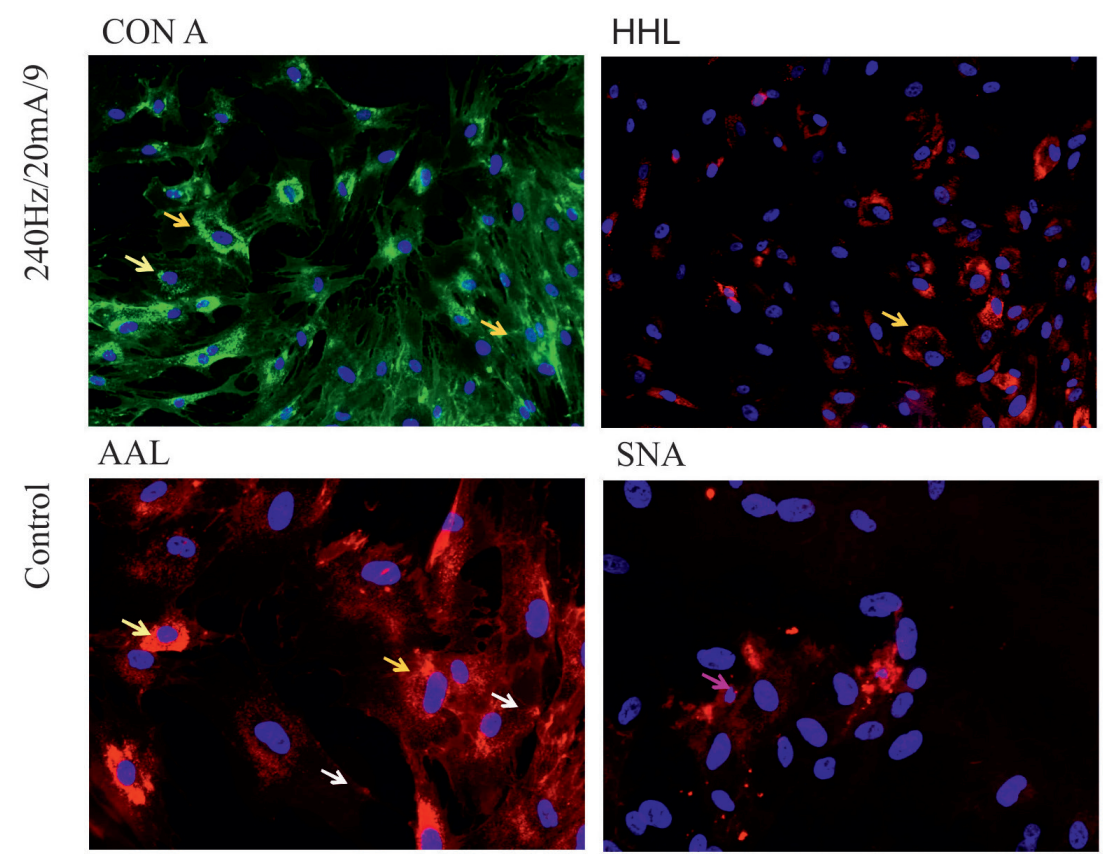

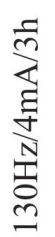

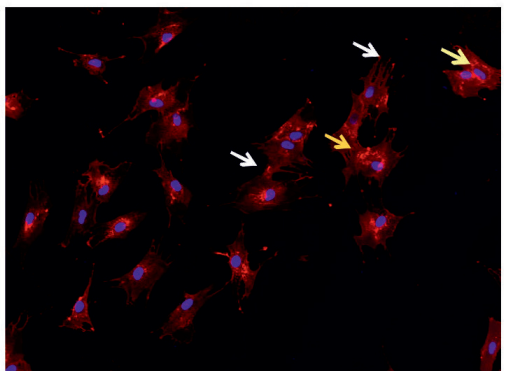

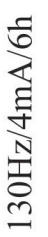

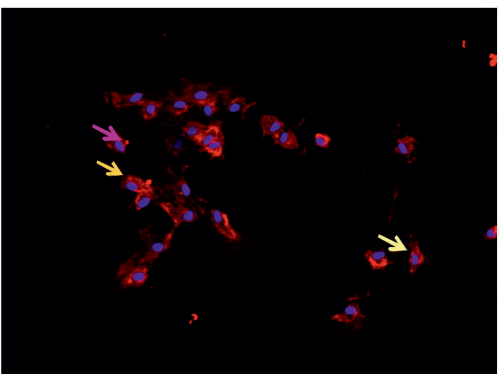

$\frac{2}{5}$
$\frac{1}{1}$
$\frac{1}{N}$
$\frac{1}{0}$
․

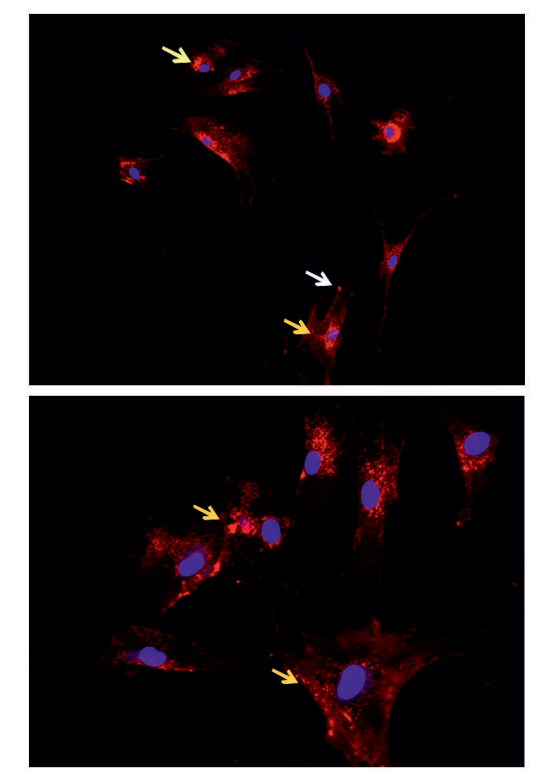

Fig. 3. Cont
$\mathrm{HHL}$

SNA

NPL

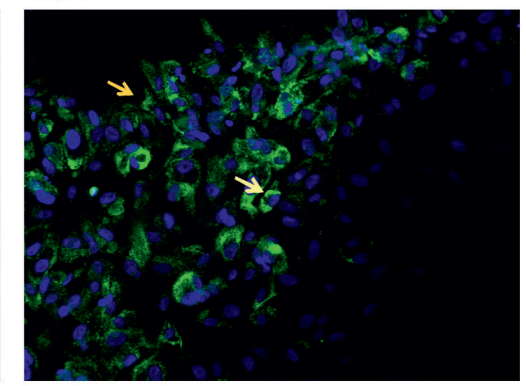

WGA
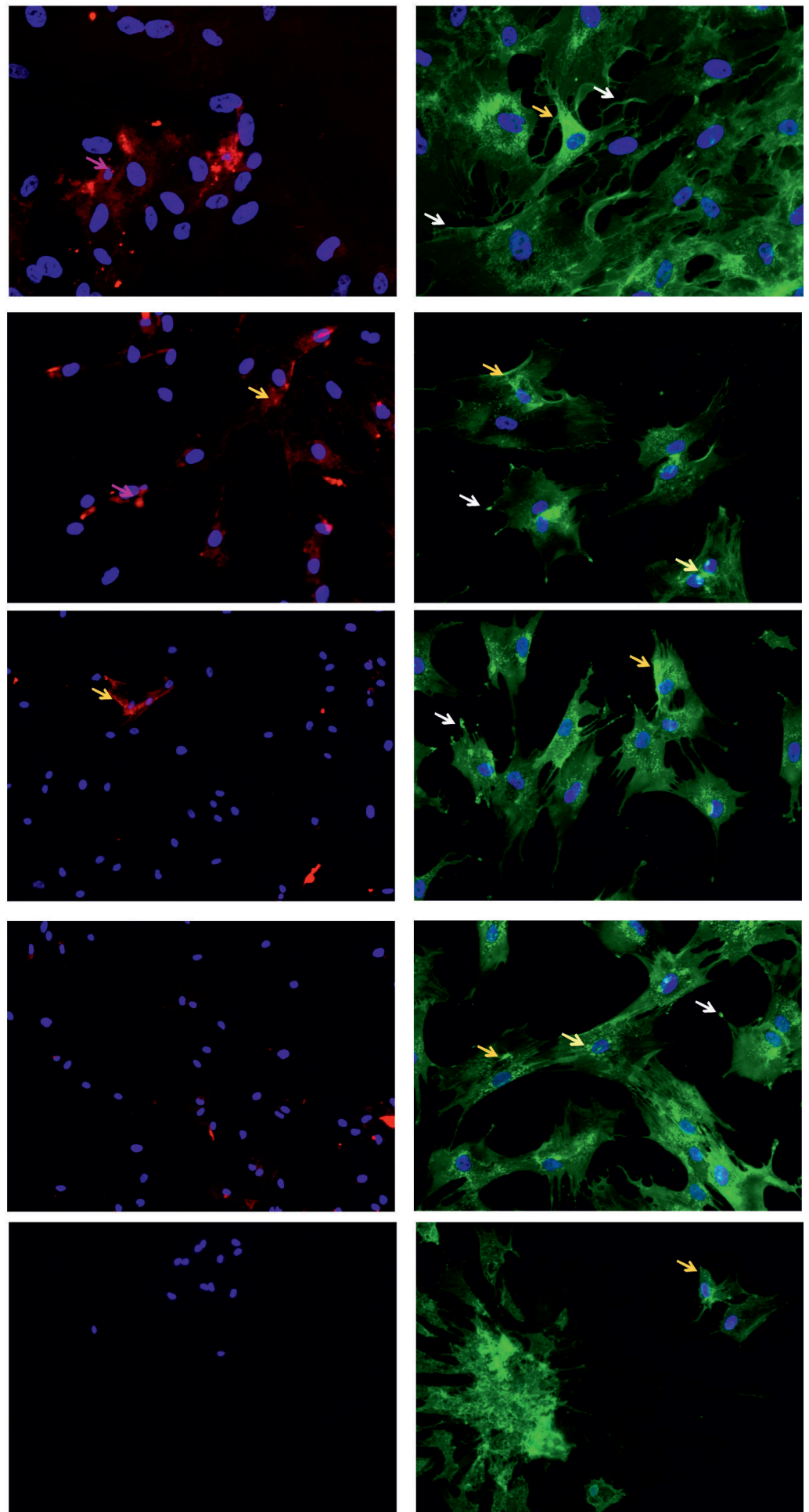


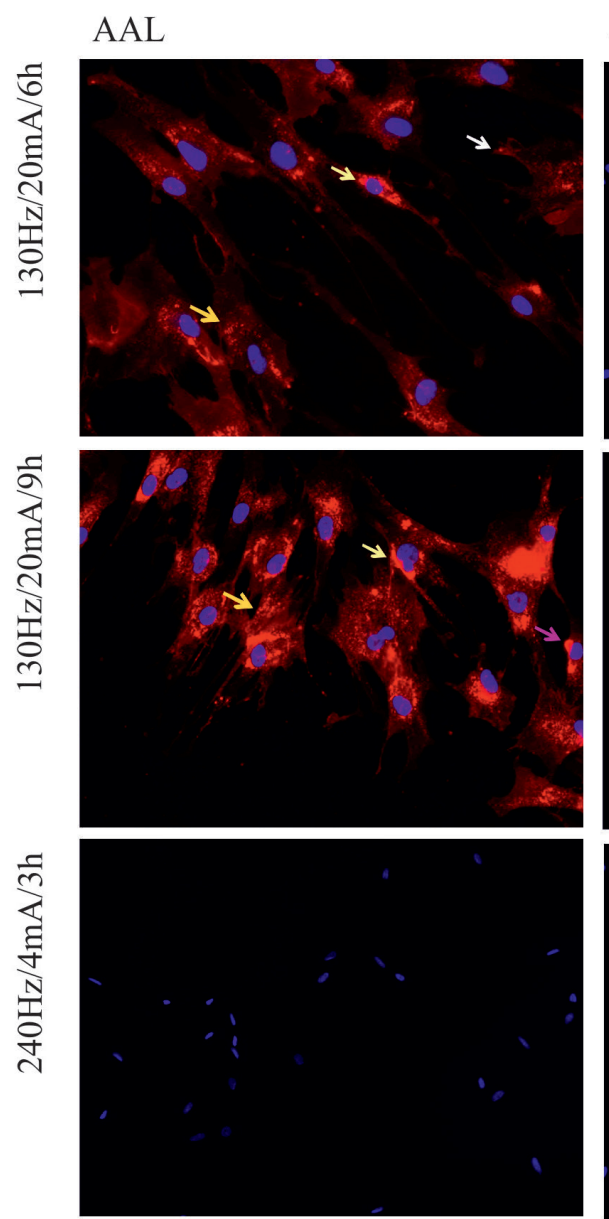

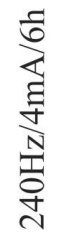
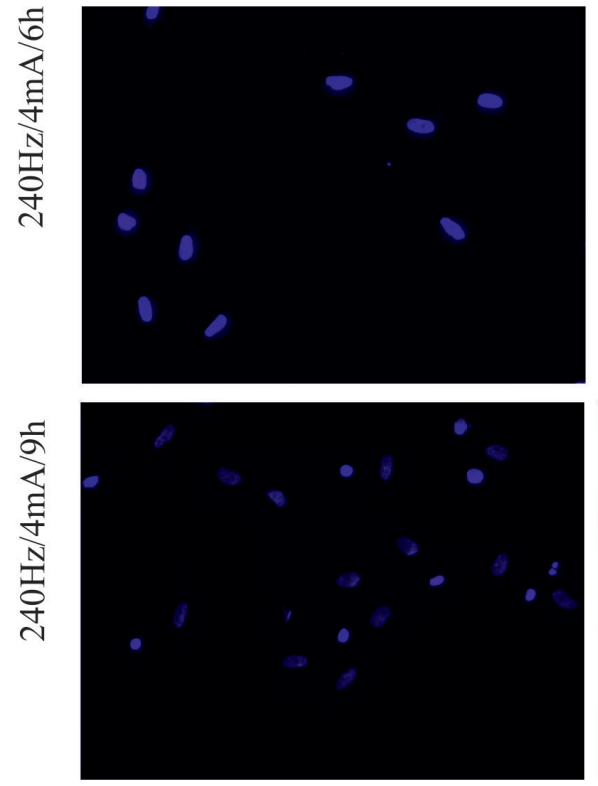

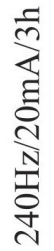

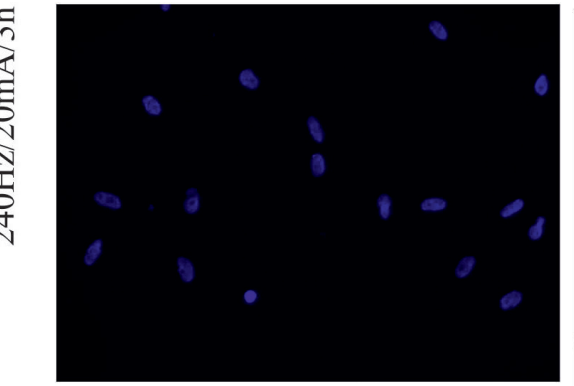

SNA
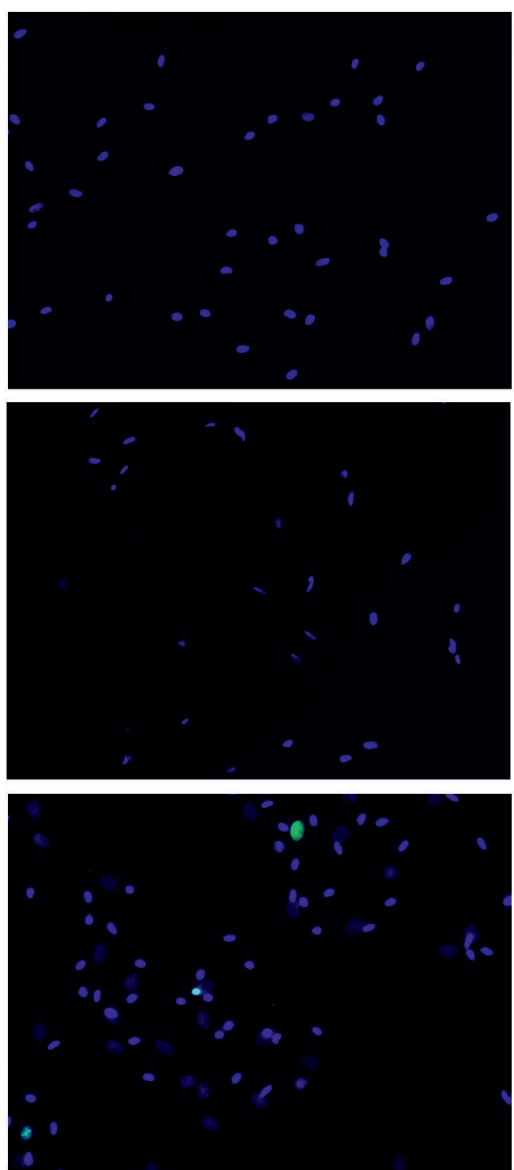

WGA
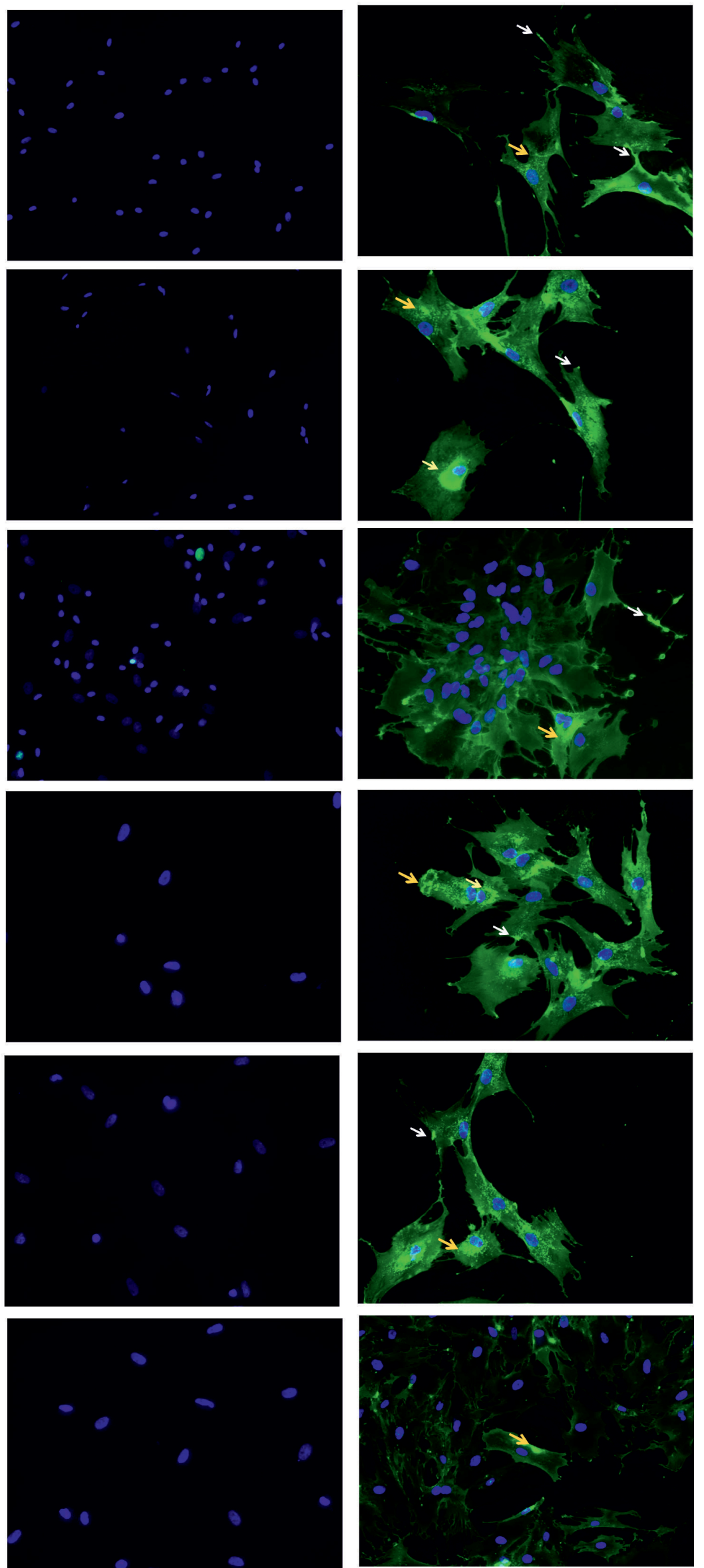

Fig. 3. Cont 

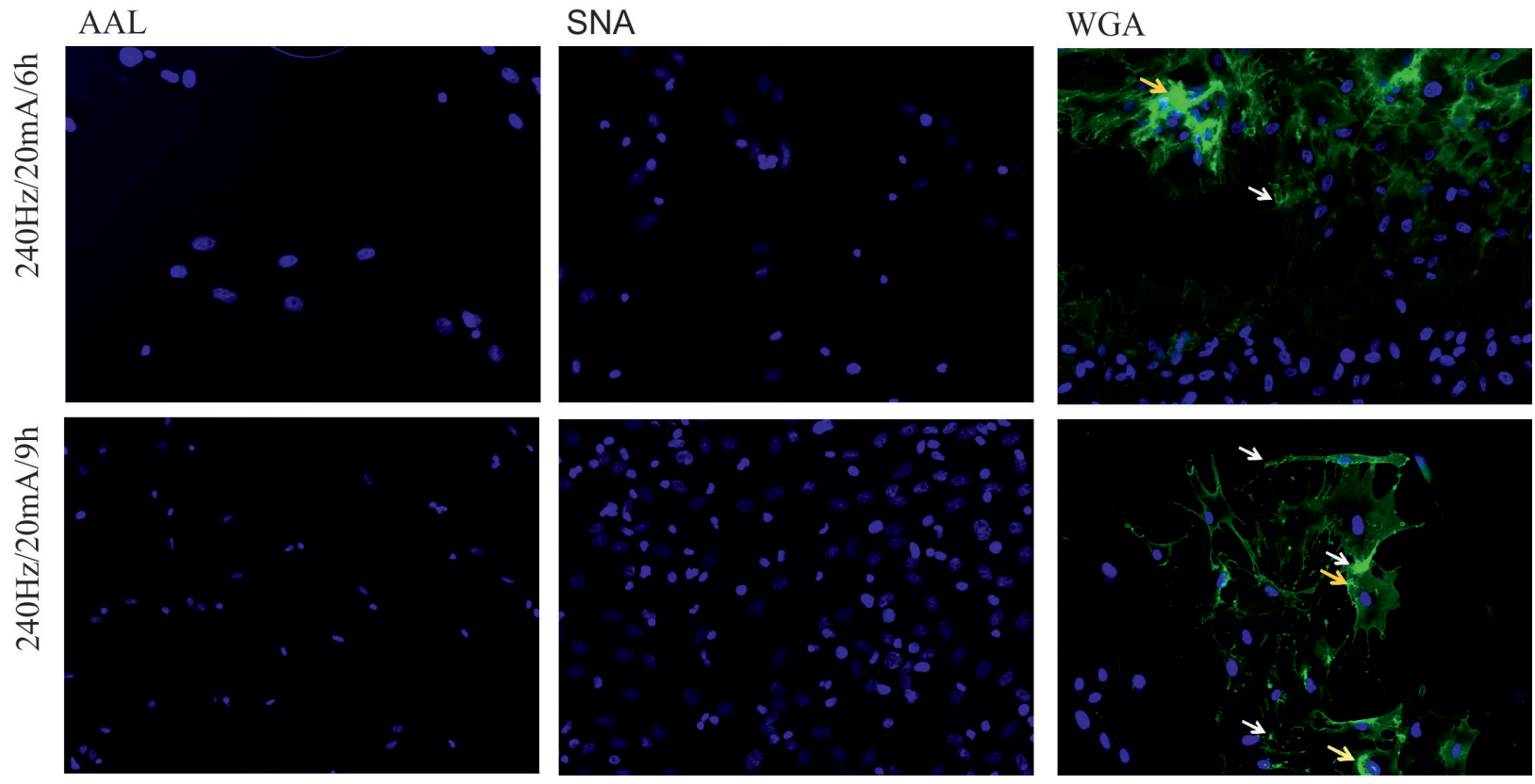

Fig. 3. Cont.

of straightness, as well as changes in the profile of cell surface glycans using 6 plant lectins of the specific glycanbinding properties. The most desirable results, i.e., those in which cells cover the longest possible track in one defined direction, were obtained for the field strength of $20 \mathrm{~mA}$. Under these conditions, the cells migrated for the longest distance and had the highest parameter of straightness.

There are many advantages of using a low current for EF stimulation in cells migration studies, where most importantly, excessive heat and unwanted effects on different cell types in the 3D tissue settings are prevented.,7 Zhao et al. have shown that the directional migration occurred at a low threshold and with a physiological EF of $\sim 25 \mathrm{mV} / \mathrm{mm}$, while increasing the EF-enhanced MSC migratory response. ${ }^{23}$ The authors concluded that these conditions selectively directed the migration of MSCs while potentially avoiding effects on endothelial cells and their progenitors.

The understanding of biochemical and biophysical changes occurring in cells during migration is rapidly growing. Biochemical studies include genetic manipulation of chemokines and their receptors such as CXCL12/CXCR-4, as well as stimulation of matrix metalloprotease secretion, enhancing chemotaxis and migration of stem cells. ${ }^{26,27}$ Studies investigating the effects of the EF on cell migration show profound changes in the membrane electrical state due to the electrostatic membrane surface charge and altered electrodynamic ion fluxes through the membrane channels, resulting in cell membrane permeability changes followed by alterations of cytoskeleton structure. ${ }^{12,28,29}$ There is also a growing number of reports documenting profile changes of membrane receptors, i.e., epidermal growth factor receptor (EGFR), Ca2 ions, and changes in expressions of cytoplasmic signaling proteins such as extracellular signal-regulated kinase (ERK), p38 mitogen-activated kinase (MAPK), cellular sarcoma gene family kinases (Src), protein kinase $B(\mathrm{PKB})$ serine/threonine-specific protein kinase (Akt), and phosphatidylinositol-3 kinase (PI3K). ${ }^{30,31}$

The ability to recognize distinct carbohydrate determinants turned certain plant lectins into very valuable tools in blood typing, in evaluating cell differentiation processes, as cell separation and characterization agents, as markers used in microarrays, in immunological studies, and in studies of cell-cell recognition and cell signaling processes. ${ }^{32-36}$ The importance of glycans in cell therapy has been known since 1988, when Hardy and Tavassoli showed that the carbohydrate moieties present on the stromal cells were important in homing stem cells bearing the corresponding lectin-like molecules and membrane lectins on a stem cell surface with a specificity for galactose and/or mannose-bearing glycoconjugates involved in the successful engraftment of hemopoietic progenitor cells in their specific stromal microenvironment. ${ }^{37}$ Similarly, Hinge et al. showed that the mannose-containing carbohydrate moieties present on the hematopoietic stem and progenitor cells were recognized by mannose-binding lectins and played an importantrole in the HSPC-protecting effect of these lectins. ${ }^{38}$ The protective effect of mannose-binding lectins has also been demonstrated by Li et al., where the effect of a mannose-binding lectin, NTL, purified from Narcissus tazetta var. chinensis, prolonged the maintenance and expansion of cord blood CD34+ cells. The results of this study indicate that the effect of NTL on the long-term preservation and expansion of early stem/multilineage progenitor cells might be useful in cell therapy strategies for DC34+ cells intended for transplantation. ${ }^{39}$

Much effort has gone into understanding the mechanisms of glycosylation and glycan modification within the ER and the Golgi apparatus. Enzymes involved in this 
process are well-studied, which helped to define various functional compartments of the ER-Golgi pathway. We observed signals within different compartments of ER, both in the Golgi vesicles and around the nucleus. Signal closed to the nucleus varied depending on the direction of the EF. In certain EF conditions, signal appeared highly concentrated, forming a very characteristic cap on one side of the nucleus, and called here "polarized ER" (ERp). Similar observation was made by $\mathrm{Pu}$ and Zhao. ${ }^{20}$

In summary, our result show that: (i) EF value affects the rate of cell migration in contrast to the EF frequency; (ii) the rate of migration increases with the EF intensity above physiological levels, whereas EF at physiological levels did not affect cell motility, which may be important for the maintenance of the transplanted cells at the lesion site; (iii) EF above physiological levels resulted in changes of the cell surface glycans, whereas physiological EF levels did not change the cell glyco-phenotype as indicated by the lectins used in this study. Since the complex glycosylation of glycolipids and glycoproteins on cell surfaces forms a sophisticated architectural 3D-structure, creating the largest cell-surface and cell-substrate adhesion area, changes in this 3D-structure will have a large impact on all properties of cellular adhesion and motility. ${ }^{40}$ The significance and novelty of our approach is based on (i): the recognition of the importance of the dynamics and regulatory function of structural cell surface glycosylation, and (ii) creating (formulating) a novel approach to studies of stem cell membrane glycosylation-based dynamics using a set of lectins binding cell surface carbohydrates.

The success of the stem cell transplantation depends on the effective and functional integration of transplanted cells into the patient's body and into the specific environment of extracellular matrix (ECM) produced and secreted by surrounding native cells. Based on the date results with the targeted cell migration, we used the low value EF remaining within the patient's tolerance range, which is a crucial factor in the cell therapy. Our results show that the application of well-tolerated stimulation parameters should allow securing the transplanted cells at the lesion site, without affecting the phenotype-surface glycans, thus providing a graft that is likely more compatible with the host environment.

If the goal of the stem cell-based therapy is to deliver cells to the lesion site and keep them there, it seems reasonable to reevaluate the concept of transplanted cells' homing. Perhaps it is better to choose stimulation/neuromodulation parameters that do not trigger cells to move, but instead keep the cells at the lesion site and prevent their migration to other tissues. Therefore, using the dedicated system for spinal cord stimulation/neuromodulation may provide us with a readily available tool for improving the effectiveness of stem cell therapy.

The use of plant lectins marking specific types of complex glycans allowed us to follow the reprograming of the cell surface glycosylation in response to certain PEF. Here, the specific changes in the cell surface glycans were observed only in cells showing directional movements under treatment with PEF above the physiological level, but in other conditions, such changes may indicate the unwanted migratory potential of cells intended for restorative transplantation.

\section{Conclusions}

The analysis of the stem cells' glycome dynamics at different stages of differentiation and migration makes possible the exploration of the cell surface glycans as markers of the stem cell functional status, and, in the future, compatibility between transplanted cell and host environment. Recently, substantial research effort focuses on changes in glycan profiles during differentiation of germ cells or induced pluripotent cells (iPS). There is a growing need for a better understanding of stem cell functional roles in the self-renewal and differentiation in vivo, as well as through niche interactions and signaling modulation. Since the complex cell surface glycans play a critical role in cell differentiation and migration, we should be aware that the information about glycan dynamics and its regulation may be extensively utilized and likely contribute to the optimizations of the stem cell preparations for future therapeutic applications. For instance, collective information about the type of transplanted stem cells and the more detailed characterization of their cell surface glycomes using more extensive lectin panel recognizing different 3D glycosylation patterns, can be correlated with the success rate of the transplant and used to optimize protocols for preparations of the therapeutic biomaterial of high quality and efficacy. We believe that our results obtained here using a panel of only 6 lectins provide proof of principle, and are an important step in the characterization of stem cells for restorative grafting.

\section{References}

1. Okano $\mathrm{H}$, Sawamoto K. Neural stem cells: Involvement in adult neurogenesis and CNS repair. Philos Trans $R$ Soc Lond B Biol Sci. 2008;363:2111-2122.

2. Breitbach M, Bostani T, Roell W, et al. Potential risks of bone marrow cell transplantation into infarcted hearts. Blood. 2007;110(4): 1362-1369.

3. McCaig CD, Rajnicek AM, Song B, Zhao M. Controlling cell behavior electrically: Current views and future potential. Physiol Rev. 2005;85:943-978.

4. Barker AT, Jaffe LF, Vanable Jr JW. The glabrous epidermis of cavies contains a powerful battery. Am J Physiol. 1982;242:R358-R366.

5. Zhao M, Song B, Pu J, et al. X Electrical signals control wound healing through phosphatidylinositol-3-OH kinase-gamma and PTEN. Nature. 1982;442:457-460.

6. Ozkucur N, Monsees TK, Perike S, Do HQ, Funk RH. Local calcium elevation and cell elongation initiate guided motility in electrically stimulated osteoblast-like cells. PLoS One. 2009;4:e6131.

7. Zhao Z, Qin L, Reid B, Pu J, Hara T, Zhao M. Directing migration of endothelial progenitor cells with applied DC electric fields. Stem Cell Res. 2011;8:38-48. 
8. Zhao M, Bai H, Wang E, Forrester JV, McCaig CD. Electrical stimulation directly induces preangiogenic responses in vascular endothelial cells by signaling through VEGF receptors. J Cell Sci. 2004;117:397-405.

9. McCaig CD, Zhao M. Physiological electrical fields modify cell behavior. Bioessays. 1997;19:819-826.

10. Sato MJ, Ueda M, Takagi H, Watanabe TM, Yanagida T.Input-output relationship in galvanotactic response of Dictyostelium cells. Biosystems. 2007;88:261.

11. Li J, Zhu L, Zhang M, Lin F. Microfluidic device for studying cell migration in single or co-existing chemical gradients and electric fields. Biomicrofluidics. 2012;6(2):24121-2412113.

12. Huang C, Cheng J, Yen M, Young T. Electrotaxis of lung cancer cells in a multiple-electricfield chip. Biosens Bioelectron. 2009;24:3510.

13. Huang J, Hu X, Lu L, Ye Z, Zhang Q, Luo Z. Electrical regulation of Schwann cells using conductive polypyrrole/chitosan polymers. J Biomed Mater Res. 2009;93:164-174.

14. Rezai P, Salam S, Selvaganapathy PR, Gupta BP. Electrical sorting of Caenorhabditis elegans. Lab Chip. 2012;12:1831.

15. Alley WR Jr, Mann BF, Novotny MV. High-sensitivity analytical approaches for the structural characterization of glycoproteins. Chem Rev. 2013;113(4):2668-2732.

16. Malina W, Smiatacz M. Methods of Digital Image Processing. Warszawa, Poland: Academic Publishing House - Exit; 2005:159-176.

17. Batchelor B, Waltz F. Interactive Image Processing for Machine Vision. London, UK: Springer-Verlag; 2012:17-45

18. Zieliński KW, Strzelecki M. Computer Analysis of Biomedical Image. Warszawa, Poland: Scientific Publishing House - PWN; 2002:170-178.

19. Jezierska-Woźniak K, Wojtkiewicz J, Grabarczyk Ł, Habich A, Lipiński S, Maksymowicz W. The effect of pulsed electric field on mesenchymal stem cell direct migration. IFMBE Proceedings. 2016;53:159-162.

20. Pu J, Zhao M. Golgi polarization in a strong electric field. J Cell Sci. 2005;118:1117-1128.

21. Li J, Lin F. Microfluidic devices for studying chemotaxis and electrotaxis. Trends Cell Biol. 2011;21:489.

22. Huang Y-J, Samorajski J, Kreimer R, Searson PC. The influence of electric fields and confinement on cell motility. PLoS One. 2013;8:1-9.

23. Zhao Z, Watt C, Karystinou A, et al. Directed migration of human bone marrow mesenchymal stem cells in a physiological direct current electric field. Eur Cell Mater. 2011;29(22):344-358.

24. Hart FX, Laird M, Riding A, Pullar CE. Keratinocyte galvanotaxis in combined DC and AC electric fields supports an electromechanical transduction sensing mechanism. Bioelectromagnetics. 2013;34:85-94.

25. Jahanshahi A, Schonfeld L, Janssen ML, et al. Electrical stimulation of the motor cortex enhances progenitor cell migration in the adult rat brain. Exp Brain Res. 2013;231(2):165-177.

26. Fong EL, Chan CK, Goodman SB. Stem cell homing in musculoskeletal injury. Biomaterials. 2011;32:395-409.
27. Miller RJ, Banisadr G, Bhattachary BJ. CXCR4 signaling in the regulation of stem cell migration and development. J Neuroimmunol. 2008;198:31-38.

28. Puc M, Corovic S, Flisar K, Petkovsek M, Nastran J, Miklavcic D. Techniques of signal generation required for electropermeabilization. Survey of electropermeabilization devices. Bioelectrochemistry. 2004; 64:113-124.

29. Kojima J, Shinohara H, Ikariyama Y, Aizawa M, Nagaike K, Morioka S. Electrically promoted protein production by mammalian cells cultured on the electrode surface. Biotechnol Bioeng. 1992;39:27-32.

30. Fang KS, lonides E, Oster G, Nuccitelli R, Isseroff RR. Epidermal growth factor receptor relocalization and kinase activity are necessary for directional migration of keratinocytes in DC electric fields. J Cell Sci. 1999;112:1967-1978.

31. Huang L, Cormie P, Messerli MA, Robinson KR. The involvement of $\mathrm{Ca} 2+$ and integrins in directional responses of zebrafish keratocytes to electric fields. J Cell Physiol. 2009;219:162-172.

32. Wu D, Ma X, Lin F. DC electric fields direct breast cancer cell migration, induce EGFR polarization, and increase the intracellular level of calcium ions. Cell Biochem Biophys. 2013;67;1115-1125.

33. Yura $H$, Kanatani $Y$, Ishihara $M$, et al. Selection of hematopoietic stem cells with a combination of galactose-bound vinyl polymer and soybean agglutinin, a galactose-specific lectin. Transfusion. 2008;48: 561-566.

34. Naeem A, Saleemuddin M, Khan RH. Glycoprotein targeting and other applications of lectins in biotechnology. Curr Protein Pept Sci. 2007:8:261-271.

35. Tao SC, Li Y, Zhou J, Qian J, Schnaar RL, Zhang Y, et al. Lectin microarrays identify cell-specific and functionally significant cell surface glycan markers. Glycobiology. 2008;18:761-769.

36. Kullolli M, Hancock WS, Hincapie M. Preparation of a high-performance multi-lectin affinity chromatography (HP-M-LAC) adsorbent for the analysis of human plasma glycoproteins. J Sep Sci. 2008;31: 2733-2739.

37. Hardy CL, Tavassoli M. Homing of hemopoietic stem cells to hemopoietic stroma. Adv Exp Med Biol. 1988;241:129-133.

38. Hinge AS, Limaye LS, Surolia A, Kale VP. In vitro protection of umbilical cord blood-derived primitive hematopoietic stem progenitor cell pool by mannose-specific lectins via antioxidant mechanisms. Transfusion. 2010:50(8):1815-1826.

39. Li K, Ooi VE, Chuen CK, et al. The plant mannose-binding lectin NTL preserves cord blood haematopoietic stem/progenitor cells in longterm culture and enhances their ex vivo expansion. $\mathrm{Br} J$ Haematol. 2008;140(1):90-98.

40. Amano M, Yamaguchi M, Takegawa Y, et al. Threshold in stage-specific embryonic glycotypes uncovered by a full portrait of dynamic $\mathrm{N}$-glycan expression during cell differentiation. Mol Cell Proteomics. 2010;9:523-537. 